\title{
The Relevance of Current Ethiopian Primary School Teacher Education Program for Pre-service Mathematics Teacher's Knowledge and Teacher Educator's Awareness about Mathematics Knowledge for Teaching
}

\author{
Anteneh Tefera ${ }^{1 *}$, Mulugeta Atnafu ${ }^{2}$, Kassa Michael $^{2}$ \\ ${ }^{1}$ Dire Dawa University, ETHIOPIA \\ ${ }^{2}$ Addis Ababa University, ETHIOPIA
}

Received 22 September 2020 - Accepted 3 March 2021

\begin{abstract}
The major objective of this study was to examine the effect of Ethiopian pre-service primary school teacher education program to mathematics teacher's knowledge and assess teacher educator's awareness about Mathematics Knowledge for Teaching. The study employed quantitative and qualitative research approaches. It was also used survey and narration research design. The population of this study were all third-year pre-service teacher classes in generalist, specialist and linear modality classes in three sampled colleges of teacher education such as: Kotebe Metropolitan University, Hawassa College of teacher education and Arba Minch college of teacher education. The sampling technique used was purposive sampling. The result showed that program type has no effect on the mean scores between specialist and linear students in Mathematics Knowledge for Teaching scale. Significant difference was not observed in mean score of Mathematics Knowledge for Teaching test against gender. The findings also showed that teacher educators have no enough knowledge/awareness about the term Mathematics Knowledge for Teaching and its components. Thus, the study suggested that successive training should be organized to train teacher educators about Mathematics Knowledge for Teaching and mathematics pedagogies and recent mathematics education theories in general.
\end{abstract}

Keywords: relevance, primary school, pre-service teacher education, mathematical knowledge for teaching, awareness

\section{INTRODUCTION}

In the last four decades, science and mathematics teacher education has made essential developments on improving and strengthening ways of producing qualified teachers. This is because there is common understanding among scientific communities that this was the main tool for sustainable development and it was assumed that mathematics, as one important subject, filled all facets of human endeavor. Moreover, it is the fact that students who have deficiencies in mathematics contents are unable to employ mathematics concepts, principles and skills in the course of their science education (Adelodun, 2014).

Thus, to produce highly competent students in mathematics who are able to understand mathematics and its application in science and technology, college of teacher education must ensure that their pre-service teachers have opportunities to develop the necessary mathematical knowledge that is vital to their future teaching profession (Lee, Meadows, \& Lee, 2003). This is because this knowledge is one of the biggest components that influences classroom atmosphere and student achievement (Fennema \& Franke, 1992), and the quality of mathematics teaching (Ball, Hill, \& Bass, 2005). In purist of this, several efforts have been done worldwide to understand the knowledge that pre-service school mathematics teachers acquire during their teacher preparation. In addition, researchers have struggled to classify and clearly define all of the elements comprising the knowledge teachers needing for teaching (Thames \& Ball, 2010).

Several studies and reforms were done internationally since world war II, especially after

(c) 2021 by the authors; licensee Modestum. This article is an open access article distributed under the terms and conditions of the Creative Commons Attribution License (http://creativecommons.org/licenses/by/4.0/). 


\section{Contribution to the literature}

- This review adds values to the current theoretical assumptions about the mathematical knowledge of pre-service mathematics teachers that should acquire at the end of the program.

- It provides brief summary about what mathematical contents teacher education program should encompass in order to produce proficient primary school mathematics teachers.

- It also provides valuable information about the knowledge of mathematics teacher educators with respect to MKT.

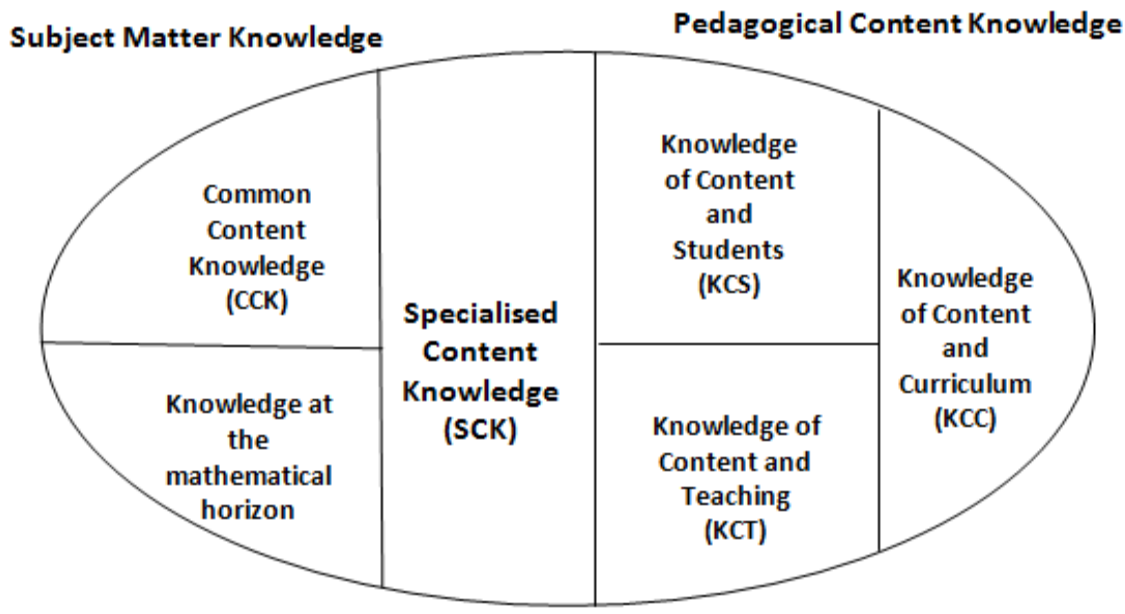

Figure 1. Mathematical Knowledge for Teaching (MKT) (Ball et al., 2008)

sputnik launch, in order to made mathematics education better and better-quality education. Ideological shifts were also observed towards 1990s and 2000s from cognitive orientation to constructive and socio-cultural orientation. As a result, Shulman came up with new important theoretical model of pedagogical content knowledge (PCK) in teacher education which constitutes a special amalgam of pedagogy and content knowledge. He claimed that PCK identifies the distinctive bodies of knowledge for teaching that represents an understanding of how particular topics, problems or issues, are organized, represented and adapted to the diverse interests and abilities of learners, and presented for instruction (Shulman ,1987).

The introduction of Shulman's PCK framework served as the baseline/platform for the emerging of several theoretical models to understand the unique mathematical knowledge necessarily needed for teachers like Grossman framework in 1990, Fennema and Franke framework in 1992, Even's framework in 1993, Koehler and Mishra model of Technological Pedagogical Content Knowledge (TPCK) in 2005, and Ball, Thames, and Phelps model of Mathematical Knowledge for Teaching (MKT) in 2008.

Ball, Thames, and Phelps (2008) supposed that teaching mathematics is the process of conveying mathematical knowledge and concept to learners in compressed form. It is a way of translating integrated understandings of content into classroom practice, transmitting knowledge, guiding and helping students to construct their own knowledge. Consequently, they introduced the term mathematical knowledge for teaching (MKT) to describe the knowledge that is needed by teachers and it is defined as the mathematical knowledge, skills and, habits of mind needed to carry out the work of teaching mathematics. Finally, they have developed a practice-based and discipline grounded new framework that expanded Shulman's knowledge of categories by dividing them into pieces. The model consists of two components: subject matter knowledge (SMK) and pedagogical content knowledge (PCK). Each sub divided in to three sections as shown in Figure 1.

Common content knowledge (CCK) is concerned about mathematical knowledge and skill used in a wide variety of setting, not unique to teaching. This knowledge helps teachers to know the material they teach or the mathematics in student curriculum. This plays a great role in planning and carryout classroom instruction. The specialized content knowledge (SCK) is the mathematical knowledge and skill unique to teaching such responding to students "why" questions, finding an example to make specific mathematical points and evaluating mathematical explanations. The third is knowledge at the mathematical horizon which is about the connections/relation among various topics over the span of mathematics courses.

The pedagogical content knowledge (PCK) includes three sub-categories as it is indicated in Figure 1. Knowledge of content and student (KCS) is the knowledge that combines knowing about students and knowing about mathematics. This basically is about what students are likely to think and what they will find 
confusing. While Knowledge of content and teaching (KCT) concerns about sequences of particular mathematical contents for teaching. Its central tasks are evaluating the instructional advantages and disadvantages of some particular instructional method(representations) used to teach a specific idea and knowing what different methods and procedures afford instructionally. For example, which examples to start with and which to use to take students deeper in to content. The third is knowledge of content and curriculum. This is about all knowledge of interconnected with curriculum, pedagogy, and psychology for teaching and students. It's about how various topics of specific content area are connected and sequenced within curriculum framework (Ball, Thames, \& Phelps, 2008).

To sum up, a certain threshold of mathematical content knowledge (MCK) and pedagogical content knowledge (PCK) are very necessary for being the preservice teacher is effective in teaching career and preservice education program is expected to equip them with this minimum academic knowledge in order that they are confident to teach the subject matter, to choose and apply appropriate teaching methods during their professional career.

\section{Mathematics Teacher Educator's Knowledge}

Teacher educators are teaching young students in post-secondary where the mathematical content is assumed to be in the context of school mathematics and the content is itself linked to primary school Mathematical knowledge of common, specialized, and horizon subject matter knowledge (Hauk, Jackson, \& Tsay, 2017). But what is the nature of mathematical knowledge for teaching (MKT) for teacher educators who are teaching mathematics for pre-service school teachers? and how is their awareness about it? are the two key questions that are getting focused in teacher education research in recent time.

Even though it is difficult to give detail explanation about what knowledge and skills are required to be an effective mathematics teacher educator or how those knowledge and skills develop (Gallagher, Floden, \& Gwekwerere, 2012). Hauk, Jackson, and Tsay (2017), tried to give explanation about the knowledge of teacher educators needed to teach pre-services. They called it as mathematical knowledge for teaching pre-services (MKT-FT) and they assumed that mathematics teacher educators construct MKT-FT as they teach courses for pre-services. Its specialized content knowledge includes an awareness of and responsiveness to the educational literature as a means of helping pre-services understand why certain mathematical practices or pedagogical practices are favored. Its horizon knowledge includes recognition of mathematics standards at various region, district, state, and national.
Furthermore, Jonasson (2010) indicated that knowledge which are required by teacher educators, which are distinct from those required by other teachers may include the pedagogy of educating teachers, educational studies, practice-based research, schools as institutions, professionalism, the discipline as school subject, the discipline didactics, general didactics, school-based education and new skills. Therefore, as various literatures indicated very special and diversified knowledge are required to have by teacher educators which made them very proficient for training teachers.

Beside the professional knowledge needed, teacher educators also are expected to do a variety of tasks such as teach a subject or pedagogy and support students who do field work. Moreover, teacher educators are increasingly expected to develop and carry out courses for experienced teachers and to do research (Koster, Dengerink, Lunenberg, \& Korthagen, 2008).

In Ethiopia, though much research is not available in the area of knowledge of teacher educator, the policy clearly indicated that at least they should have bachelor's degree in their specialization area. It is assumed that those who have bachelor have enough knowledge and are capable to teach teachers. In general speaking, in Ethiopia, primary school pre-service teachers are taught the courses designed in the curriculum by two types of teacher educators: those who teach the content courses like mathematics and those who teach professional courses like pedagogical courses.

\section{Content of Mathematics Education in Teacher Education Programs}

Pre-service teacher education program has a great role on the overall professional development of teachers along their professional career and it is a gateway and initial step for teacher professionalism. This professional development would be described in terms of the knowledge, skill and behaviour they acquired in college of teacher education. Thus, as Osaki (2001) asserts there should be a balanced curriculum for teacher education that includes a harmonious blend of academic component, pedagogy and practice. A balanced curriculum means a curriculum planned in totality, not in piecewise fashion (Kelly, 1999).

Regarding the knowledge, the subject matter knowledge component is concerned with competence in the teaching subject (mathematics). It is a technical knowledge of the subject mathematics. Furthermore, Ball, Hill, and Bass (2005) states that how well teachers know mathematics is central to their ability to use instructional materials, assess student progress, and make sound instructional decisions. When teachers have well integrated content knowledge, they are able to teach dynamically single concept with many representations, whereas those who have inadequate content knowledge may highly depend on single source explain single 
mathematical principles, most probability it is textbooks (Sutton \& Krueger, 2002).

Pedagogy is concerned with professional competence like ability to involve students in the teaching and learning process (Meena, 2009). Courses for primary teacher education must include a development of pedagogical skills which help teachers to understand how students learn mathematics and will equip them with a range of teaching techniques and practices (NCTM, 2000). The practical experience or practicum refers to participation in the field work at schools (Bjarnadottir, 2007). Lewin and Stuart (2003) described it as it is an opportunity for the pre-services to bring all other components together and practice the role of a teacher.

In addition to the above, different authors described the professional knowledge of teachers needed for teaching in various ways. For example, Ball et al, (2008) claimed that the combination of subject matter knowledge and pedagogical content knowledge is the main determinant to teach mathematics at primary schools, which is commonly known as mathematical knowledge for teaching (MKT). However, Hiebert, Morris, and Jansen (2007) believed that teachers should acquire at least three constructs which would enable them to teach the subject in primary schools: knowledge, skills and dispositions. Ball (1990) strengthened the ideas in that this knowledge can change teachers' knowledge, assumptions, and feelings about mathematics as well as their beliefs regarding their role as mathematics teachers in the classroom.

Aggregating these all conceptions, the main factors which determine the nature and content of primary mathematics teacher education regardless of the physical resource inputs is the mathematical knowledge they have at the end of the program. Teacher's knowledge would include mathematical content knowledge, pedagogical content knowledge.

\section{Current Primary School Teacher Education program in Ethiopia}

In Ethiopia, the primary education is organized in two cycles: the first cycle (grade 1-4) or basic education cycle and the second cycle (grade 5-8) or general primary cycle. Teacher education colleges also prepare teachers for first cycle and second cycle teaching in three modalities. The generalist modality prepares teachers for lower primary grades 1-4. It is a composite of four subject areas, plus common, professional and practicum courses. The linear modality prepares teachers for upper primary grades 5-8 in a major and minor subject, plus common, professional and practicum courses, and specialist prepares teacher for grade 5-6 (MoE, 2013).

\section{Statement of the Problem}

Teaching mathematics has become more challenging worldwide as knowledge demands change, lack of consensus among scholars and existence of wide alternatives of theoretical base (Tatto, Peck, Schwille, Bankov, Senk, Rodriguez, \& Rowley, 2012). Still there are also many discussions among educators on teacher's mathematical knowledge for teaching (MKT) (Hill \& Ball, 2009). Furthermore, research finding conducted in last few decades indicated that significant number of mathematics teachers exhibit lack of confidence on mathematical knowledge and mathematics teaching, and weakness in fundamental and deep conceptual understanding of mathematics when they teach mathematics (Mapolelo \& Akinsola, 2015).

In Ethiopia, after education and training policy was publicized in 1994, mathematics and science became the two basic academic subjects that form the foundation of the education and training programs across the education program including in teacher education. The Ethiopian government has initiated a countrywide teacher education and training program which aims to increase the relevance and quality of mathematics education. To realize this, for primary teacher education, a three-year diploma concurrent program was designed in order to equip mathematics pre-services with the knowledge and skills of the subject matter (academic content), methods of teaching subject (pedagogy content), theory-practice connection (practicum) and general pedagogy for teaching primary grades. The provision of academic, pedagogy content knowledge and general pedagogical courses to mathematics preservice teachers in the college aims to help them to have adequate subject matter knowledge to teach curriculum contents of primary grades subjects, develop intellectually \& socially and to have in depth knowledge of learning how to teach.

Nevertheless, the overall preparation process of teachers has been criticized in terms of provision of quality teaching and better-quality education for preservice teachers which enable them to develop the required knowledge. This is reflected on objectives, content knowledge, ways of practical teaching experiences, instructional methods, assessment techniques used, and motivation towards their profession and commitment (UNICEF, 2010; Workneh \& Tassew, 2013). In addition, the Ethiopian ministry of education $(\mathrm{MoE})$ in this regard has conducted number of assessments at national level. For example, the study conducted in 2002 on the Quality and Effectiveness of Teacher Education in Ethiopia showed that many teacher educators were not professionally trained, teacher education curricula are based dominantly on the development of academic knowledge, and weak preservice training and absence of continuous professional development opportunities. As a result, they 
recommended that the urgent need to bring about a paradigm shift in the teacher education system of the country (MoE, 2006).

In addition, though many studies were not found specific to teacher's mathematics knowledge, there are few studies which unfold weak performance of mathematics educators on knowledge of mathematics teaching-learning methods that is essential to implementing fruitful changes in the classroom learning culture (Birhanu, 2010), and school teacher's weak mathematical knowledge (Yohannes, 2007). Furthermore, Workneh and Tassew (2013) during their young lives school survey found that lack of pedagogical knowledge, particularly about applying studentcentered methods of teaching is one of the major challenges for primary schools teachers. They believed that the ways of preparation of teachers had greatly contributed to improving teacher quality.

As a result of these criticisms, the curriculum of preservice primary teacher education program was reformed and restructured in 2013. However, study at national level by MoE and other studies indicated that the questions of quality education after 2013 are still continued in terms of Mathematical knowledge, professional competency of teachers and professionalism in teacher education program (MoE, 2016).

All the above studies were generic. They discussed the overall situations of teacher education in Ethiopia. However, there are no as such studies about MKT of mathematics teacher educators and pre-service mathematics teachers in Ethiopia. Of course, there are some research on PCK and Technological Pedagogical Content Knowledge (TPCK) of teachers and /or preservice teachers of various specializations like analysis of methodology courses contents of teacher education curriculum with that of PCK and professional knowledge (Dawit \& Alemayehu, 2001), and TPCK of pre-service mathematics teachers and association among its components (Kassa, 2014).

Therefore, teacher education program needs to be assessed for its effect to the development of necessary mathematical knowledge (MKT) for future professional teaching career of pre-service teachers. Thus, it is with this understanding that this study focuses on examining the pre-service primary mathematics teacher's mathematical knowledge and teacher educator's awareness about MKT.

\section{Research Questions}

This study poses the following questions to investigate the Ethiopian primary school pre-service teacher education and its relevance to mathematics teacher's knowledge development in terms of gender and modality. It is obvious that the outcome of different program type (modality) has different impact on student's performance. Gender also included because there are number of different explanations about the existence of gender difference (can be small or large) in math- related career choice and performance (Ganley \& Lubienski, 2016). Thus, the questions were:

1. To what extent do pre-service teachers acquire mathematical knowledge for teaching by the end of teacher education in terms of gender and modality?

2. How aware are mathematics teacher educators about Mathematical knowledge for teaching?

\section{RESEARCH DESIGN AND METHODS}

To achieve its objectives, the study has designed two research questions. In order to answer these research questions, the study employed both quantitatively, survey test and qualitatively, narrations research approaches. Both independent data were collected and analyzed independently and the results were merged in order to understand the relevance of the teacher education program on mathematical knowledge development of pre-service mathematics teachers.

Furthermore, it used only primary data source of data for gathering relevant information to answering the research questions. So, its primary source of data are graduate mathematics pre-service teachers and teacher educators. To collect these primary data, the study used interview, questionnaires, and survey tests.

\section{Population, Sampling and Sampling Technique}

The population of this study were all third-year preservice teacher classes in generalist, specialist and linear modality classes in the sampled colleges of teacher education. This is because the graduate students are expected to know the program very well and already developed some knowledge as a result of the teacher education program. The others population that was going to participated in the study, were teacher educators at CTEs.

In doing so, this study was used three colleges of teacher educations as sites of the study which are located in Addis Ababa city, and South Nation Nationalist and People's (SNNP) region. These were: Kotebe Metropolitan University from Addis Ababa city (AA), Hawassa College of teacher education and Arba Minch college of teacher education from SNNP region. It did not include CTEs of other regions since they used their local language as a medium of instruction fully or partially. Thus, the regions were selected purposively. This is because (1) English is served as medium of instruction, (2) use the same curricula materials. From SNNP region, Hawassa, Arba Minch, and Hossana CTEs were selected randomly and Kotebe metropolitan university was taken from Addis Ababa city as it is the only CTE that train teachers in Addis Ababa. However, 
Hossana college of teacher education from SNNP region was used as a site for piloting the data gathering instruments.

In these CTEs, there are about 711 regular pre-service school mathematics trainee teachers that were graduated in 2011 E.C (2018/19 academic year). However, among these third-year pre-service teachers in all modalities, 536 (309 male and 227 female) pre-service mathematics teachers and nine purposively sampled teacher educators in the three institutions participated in the study.

\section{Instruments}

In order to answer the research questions designed in the study and to obtain relevant information, the following quantitative and qualitative instruments were used. These were:

\section{Pre-service teacher's mathematical knowledge}

To assess the effect of the courses on level of knowledge of pre-services, a quantitative instrument was developed for measuring pre-services' mathematics MKT. For this purpose, multiple choice items were adapted the scales developed by Ball and her colleagues for the Learning Mathematics for Teaching (LMT) Project at University of Michigan and were specifically designed to capture elementary school teachers' MKT (Ball, Thames, \& Phelps, 2008). These scales were consisted of proportional reasoning, Rational number, Geometry (GEO), Number Concepts and Operations (NCOP), Pattern Function and Algebra (PFA), and Probability data statistics. Before the tests were adapted from the exam bank of LMT project, the researcher had received online training and briefing from Michigan university on how the instruments were prepared, on its purposes, and on issues of checking the validity and reliability of the instruments.

Then, two set of paper and pencil tests were adapted from exam bank of LTM project, one for specialist and linear modalities and the other was for generalist modality. Each contained 30 items. To address the question of validity (content) of the instrument and to be made successful adaption, the process of item selection was guided by Ethiopian first and second cycle primary school mathematics syllabi and expert views were taken from a mathematics education doctors. First table of specification were prepared based on the allocated time of each unit in the syllabi. The allocated time converted into percent and this percent determine the number of questions each unit would have. However, topics like unit conversion, set and simple statistics were not addressed in the exam of LTM project. Thus, questions on these units were prepared here based on the training the researcher had received from Michigan University. These were question number 24, 25, 26, and 30 for generalist and for specialist, question no, 12, and 30.
An initial version of each instrument was then piloted with a sample of 45 generalist and 34 specialists $3^{\text {rd }}$ year pre-service mathematics teachers at Hossana College of Teacher Education. Before conducting any statistical analysis, those exams which have not properly answered, were excluded from the analysis of the pilot study. Finally, a total of 61 (35 generalist and 26 specialist) pre-service teacher's test papers were taken for analysis of the pilot study.

To address the issue of reliability or internal consistency of the test, statistical analysis was performed using SPSS software. Initially, the value of alpha was found to be unsatisfactory below 0.7 showing that the data were showing a low degree of internal consistency. Then, in order to increase the value of alpha, based on the value of Corrected Item Total Correlation of each item, item deletion process was performed. That is, items were removed based on their value of corrected itemtotal correlation which provided the correlation of each item with the total of all the other items in the same scale. Whereas Cronbach's alpha if item deleted provided what the new Cronbach's alpha value would be when that particular item was deleted (Leech, Barrett, \& Morgan, 2008). As a result, as Cristobal et al. (2007) stated questions which had corrected item total correction value lower than 0.30 were deleted. Items were deleted one at a time starting with the one with the lowest corrected item total correlation.

Consequently, considering the above assumptions, a total of eight questions from generalist and ten items from specialist/linear were found to have corrected item total correlation either below 0.30, and they were deleted. After deletion of the items, Cronbach alpha of the MKT survey test reached a value of 0.816 for generalist and 0.829 for specialist/linear.

After the necessary modification and correction, the final 22 questions from generalist and 20 questions from specialist were selected for the final study. The former consisted of 7 number and operations, 9 geometry and 11 patterns, functions and algebra while the later was 10 numbers and operations, 8 geometry and 7 Patterns Functions and Algebra. In addition, responses for each item were coded as 1 for correct and 0 for incorrect answer with respect to the variable key. The sum of the 1 's and 0 's gave the total value for each participant. Total represented the total score of each participant on the MKT scale. Thus, generalist pre-service mathematics teachers were required to answer 22 questions which contained 53 items in it, and specialist and linear preservice mathematics teachers were required to answer 20 questions which have 49 items in it.

The final test item was administered to $3^{\text {rd }}$ year preservice mathematics teachers in Kotebe Metropolitan University, Hawassa College of Teacher Education and Arba Minch College of Teacher Education. During the administration of the tests, the researcher himself gave 
brief orientation to the candidates on its purpose, type of questions and on how they did the exam. In addition, they were able to ask question anytime whenever they have got difficulties in answering the questions. During administration of the tests, time was not limited.

\section{Mathematics teachers educator's knowledge/awareness about MKT}

Interview: In the field of social science research, the usefulness of interviews has long been recognized. That is, qualitative researchers tend to provide detailed descriptions of individuals and events in their natural settings (Weiss, 1994). Similarly, Kvale (1996) interestingly points out that, as such events are not often directly observable; talking to people would be one of the most effective methods for attaining and exploring constructs. More specifically, as interviews are interactive, interviewers can press for complete, clear answers and can probe into any emerging topics. Hence, interviewing is expected to broaden the scope of understanding investigated phenomena, as it is a more naturalistic and less structured data collection tool.

Having in mind the above-mentioned uses of interview, semi-structured interview was prepared in this study aiming to obtain basic information to determine the knowledge and awareness of mathematics teacher educators on MKT. It also helps to obtain information about their qualification and academic background (mathematics, mathematics pedagogy and general pedagogy), and teaching experience which indirectly tell us who teach pre-service teachers in college of teacher education.

\section{Interview Guide and Procedure}

Interview questions were constructed by the researcher himself after thoroughly reviewing the theoretical assumption of mathematical knowledge for teaching (MKT). The aim was to explore teacher educators' awareness of mathematical knowledge for teaching. The questions then were revised and edited by staff members of science and mathematics education department and PhD candidates of this department.

Generally, the interview questions have three main categories: the first was about their background including qualification and the second deals with special training, components of MKT and MKT itself. The third was general comments or suggestions about the teacher educator program and everything they feel about it.

Semi-structured interviews were made on teachers currently teaching any courses in Generalist, Specialist or linear modality to learn more about their instructional practices, their teaching experiences, special training taken especially on subject area methodology and to gain insight into their knowledge about mathematical knowledge for teaching (MKT) and its components. More specifically, the interview basically focused on the how was teacher educators' perspectives or awareness regarding issues such as subject matter knowledge $(\mathrm{SMK})$ and pedagogical content knowledge (PCK) and MKT.

Thus, the interview containing five open ended questions (Indirect questions like How do you think.... type) were performed followed-up with probing questions that helped to ensure what they meant. Each interview was audio-recorded and then transcribed for qualitative analysis.

To ensure reliability and validity of data, the transcribed interviews were presented to respondents to verify and confirm the contents of the interviews. In addition, the notes taken during these interviews served as another backup during the recording procedure.

Finally, transcription (verbatim/exactly word -for word) made in order to know the extent of the teacher educator's awareness of MKT and its components. In addition, interview protocol was prepared in accordance with the indicators of Mathematical knowledge for teaching (MKT) extracted from Ball et al, in 2008. Again, this would help to analyze the scripts of the interviews qualitatively.

\section{Method of Data Analysis}

To do the quantitative analyses, preliminary data analysis was made like number of girls and boys and number of total pre-service teachers under each program type. The collected data are reported comparatively to show variation in knowledge, skills and behavior development of pre-service teacher in terms of gender and study field using descriptive statistics, independent samples t-test and one-way ANOVA.

The audio records during interviews were transcribed and breakdown them under various themes interpreted accordingly to consolidate the understanding of the situation. Then, the qualitative analysis was made by transcription (word-for -word) in order to know the extent of the teacher educator's awareness of MKT and its components. This was done by analyzing each transcribed interview against interview protocol which contains indicators (definitions) of Mathematical knowledge for teaching (MKT) extracted from Ball and here colleague's work in 2008 (see Table 7 for detail).

\section{RESULT AND DISCUSSION}

This section depicts major findings of the study and the discussion of each of the findings on a relation to the current literature evidence. 
Table 1. Means \& standard deviations of MKT result across study program

\begin{tabular}{lcccccc}
\hline Modality & $N$ & Minimum & Maximum & Mean & SD & Skewness (statistics) \\
\hline Generalist & 351 & 0.00 & 53.00 & 24.15 & 7.73 & 0.076 \\
Specialist & 95 & 0.00 & 49.00 & 20.4 & 8.04 & 0.007 \\
Linear & 90 & 0.00 & 49.00 & 21.66 & 10.91 & 0.895 \\
\hline
\end{tabular}

Table 2. Test of Homogeneity of Variances \& test of independence using chi square across gender

\begin{tabular}{lcccc}
\hline \multirow{2}{*}{ Variables } & \multicolumn{2}{c}{ Levene's Test for Equality of Variances } & \multicolumn{2}{c}{ Independence Test using chi-square } \\
\cline { 2 - 5 } & $F$ & Sig. & $\chi^{2}$ & 0.620 \\
Generalist & 1.264 & 0.262 & 37.665 & 0.03 \\
Specialist & 0.011 & 0.916 & 39.50 & 0.235 \\
Linear & 6.303 & 0.06 & 37.393 & 0.3 \\
\hline
\end{tabular}

Table 3. Independent samples t-test in terms of total score on MKT test across modality and gender

\begin{tabular}{|c|c|c|c|c|c|c|c|}
\hline Modality & Sex & $N$ & Mean & $S D$ & $t$ & $d f$ & $p$ \\
\hline \multirow{2}{*}{ Generalist } & Male & 193 & 24.25 & 8.198 & \multirow{2}{*}{0.275} & \multirow{2}{*}{249} & \multirow{2}{*}{0.783} \\
\hline & Female & 158 & 24.03 & 7.15 & & & \\
\hline \multirow{2}{*}{ Specialist } & Male & 48 & 21.44 & 7.28 & \multirow{2}{*}{1.276} & \multirow{2}{*}{93} & \multirow{2}{*}{0.205} \\
\hline & Female & 47 & 19.34 & 8.69 & & & \\
\hline Linear & $\begin{array}{l}\text { Male } \\
\text { Female }\end{array}$ & $\begin{array}{l}67 \\
23\end{array}$ & $\begin{array}{l}21.51 \\
22.09\end{array}$ & $\begin{array}{c}8.43 \\
16.36\end{array}$ & -0.219 & 88 & 0.827 \\
\hline
\end{tabular}

\section{Result}

\section{Pre-service mathematics teacher's knowledge}

This part explicates to what extent do pre-service mathematics teachers acquire mathematical knowledge by the end of teacher education program in relation to the theory of MKT designed by Ball and her colleagues in 2007/08. This means that, students' MKT achievement indicates to what extent the implementation of curriculum of college of teacher education affected the knowledge they acquire at the end of the program.

Descriptive Statistics of the Variables of the Study

In the following section, the findings obtained from the study are presented in terms of major themes related to pre-service mathematics teacher's knowledge.

Table 1 revealed the mean score of the pre-service teachers on MKT test who trained in generality modality being found 24.15 out of a total score of 53 . Their minimum mean score was 0.00 and that of maximum result was 53. Similarly, Table 7 indicated that the mean score of specialist and linear pre-service mathematics teachers were 20.4 and 21.66 out of 49 respectively. Regarding, their minimum and maximum score, their minimum was 0.00 and 49.00 was their maximum score for both modalities. When we compare mean score of the specialist and linear, pre-service mathematics teachers in linear modality (21.66) had a mean score of little higher than the mean score of students in specialist modality (20.4).

Skewness is a common value that give insights into the normality of the distribution in descriptive statistics. It is a measure of the symmetry in a distribution and essentially measures the relative size of the two tails. Skew should be within the -2 to +2 range when the data are normally distributed (Garson, 2012; Gravetter \& Wallnau, 2014; Trochim \& Donnelly, 2006). Some authors like Mishra, Pandey, Singh, Keshri and Sabaratnam (2019). Use -1 to +1 as a more stringent criterion when normality is critical.

Based on this conception, the findings in Table 4 showed that there is sufficient condition to say score of generalists, specialist/linear pre-service mathematics teachers on MKT survey test are approximately normal since its skewness value is $0.076,0.007$ and 0.895 respectively which are within -2 and 2 .

Another statistical assumption that should be satisfied for the data before moving to analysis is homogeneity. Homogeneity testing is intended to make sure that the collected data in analysis is truly taken from a population which is too different each other. Thus, the violation of this assumption is more serious than violation of the assumption of normality (Levene, 1960). To know the homogeneity, independent sampled test was used.

Table 2 and the one-way ANOVA result shows that the assumption of equal variances (first line of $t$ test results) holds for generalist $(p=0.262>0.05)$, for specialist $(p=0.916>0.05)$ and for linear $(p=0.06>0.05)$. In addition, based on the output in Table 5 the value of Levene statistics was lower showing that higher degree of homogeneity.

The other important assumption that should be checked before doing t-test is whether the observations were independent or not. Table 6 also shows that the data were independent with respect to gender except specialist. For specialist thus, Cramer V (0.645) and Contingency coefficient $(0.542)$ are calculated and the result shows that they are not close to one. They have not strong relation. 
Table 4. Items which have high \& low scored by generalist pre-service teachers in areas of learnings

\begin{tabular}{lccc}
\hline \multirow{2}{*}{ Areas of learnings } & \multirow{2}{*}{ No of items } & \multicolumn{2}{c}{ Numbers of correct answer responders $(N=351)$} \\
\cline { 3 - 4 } Numeracy & 37 & Least correctly answered item & Highly correctly answered item \\
Measurement & 3 & 70 & 302 \\
Shapes & 9 & 91 & 258 \\
Data Handling & 4 & 204 & 263 \\
\hline Total & 53 & & \\
\hline
\end{tabular}

Table 5. High and low scored by both specialist \& linear pre-service teachers in areas of learnings

\begin{tabular}{|c|c|c|c|c|c|}
\hline \multirow{3}{*}{ Areas of learnings } & \multirow{3}{*}{$\begin{array}{l}\text { No of } \\
\text { items }\end{array}$} & \multicolumn{4}{|c|}{ Numbers of correct answers $(N=95)$} \\
\hline & & \multicolumn{2}{|c|}{ Least correctly answered item } & \multicolumn{2}{|c|}{ Highly corrected answered item } \\
\hline & & Specialist & Linear & Specialist & Linear \\
\hline Number system \& operation & 18 & 9 & 16 & 81 & 75 \\
\hline Geometry & 13 & 14 & 18 & 58 & 59 \\
\hline Algebra & 18 & 5 & 12 & 69 & 63 \\
\hline Total & 49 & & & & \\
\hline
\end{tabular}

Table 6. Comparison of MKT scale between specialist and linear modalities

\begin{tabular}{lcccccccccc}
\hline \multirow{2}{*}{ Variables } & Modality & Mean & SD & $\begin{array}{c}\text { Normality } \\
\text { (skewness) }\end{array}$ & \multicolumn{2}{c}{ Levene's test } & \multicolumn{3}{c}{ Chi square test } & \multicolumn{2}{c}{ One-way ANOVA } \\
\hline \multirow{2}{*}{ MKT Scale } & $\begin{array}{c}\text { Specialist(N=95) } \\
\text { Linear }(\mathrm{N}=90)\end{array}$ & 20.4 & 8.036 & & Sig & $\chi^{2}$ & $p$ & $F$ & Sig \\
\hline
\end{tabular}

Table 3 showed that since $(\mathrm{t}(249)=0.275$, $\mathrm{p}=0.783>0.05)$ in case of generalist modality, there was no statistically significant difference between male and female pre-service mathematics teacher's achievement in total score of MKT test. Similarly, in specialist and linear modality, there were no statistically significance between male and female pre-service mathematics teachers in total score, since $(\mathrm{t}(93)=1.276, \mathrm{p}=0.205>$ $0.05)$ and $(\mathrm{t}(88)=-0.219, \mathrm{p}=0.827>0.05)$ for specialist and linear modality respectively.

Table 4 displays the number of the participants, who gave the correct answer for each item under four areas of learning. The range of number of correct answers was from 70 (determining the result when multiplying some whole number by 4 , add 20 , divide by 2 , and subtract 10 ) to 302 (which asked to know the result of multiplying any whole number by zero) for numeracy. For measurement, the highest number of pre-service teachers who answer the question correctly were 115 (conversion of hours into minutes) and the lowest was 87 (conversion of kilometers into meters). Again, under areas of learnings shapes, the highest number was 258 (properties of figures or polygons) and the lowest number was 91 (finding perimeter of the regular figure) while the highest number for data handling was 263 (reading data from the bar graph) and lowest was 204 (finding average of data obtained from bar graph).

Similarly, Table 5 showed the highest and lowest number of the specialist/linear pre-service mathematics teachers, whose response was right, for each item across three areas of learning.

Similarly, Table 5 showed that the range of the number of correct answers were from 5 to 81 for specialist modality and 12 to 75 for linear modality. In both modality, pre-service teachers scored lower range in the same question which required to identify the correct explanation/reason why the given procedure for solving the equation $2 x^{2}=6 x$ is not correct and again they scored higher range in the same question which required them to check whether $-3+15-2$ is equal to 10 or not.

Table 6 showed that the values of skewness is between -2 and 2 which confirmed that the data are normal. In addition, even though Levene's test is significant at 0.05 level (equal group variance was violated), the ANOVA can be used since the variances are approximately equal (where equal can be defined as the larger group size not being more than $1 \frac{1 / 2}{2}$ times the size of the smaller group). In this case the larger group size is approximately 1.06 times the size of the smaller group, which is not more than $1 \frac{1 / 2}{2}$. Thus, Homogeneity of group variance was met. Thus, the one-way ANOVA $(p=0.372>0.05)$ indicated in Table 6 that there is no significant mean difference or variance difference between the two modalities and also the chi square test indicated that $(p=0.432>0.05)$, there exists enough evidence to conclude that specialist and linear mathematical knowledge result are no related (Independent). Therefore, the result shows that mean score of the two modalities have no significant difference.

\section{Mathematics teacher educator's awareness about MKT}

In this study, the word awareness means to know about, or it refers to people having generalized or diffused knowledge about the existence of something. It is frequently used interchangeably with the word 
Table 7. Indicators for Mathematical Knowledge for Teaching

MKT Indicators

Common Content Knowledge (CCK) Mathematical knowledge and skills not unique to teaching.

Specialized Content Knowledge

(SCK)

Mathematical knowledge and skills unique to teaching, mathematical tasks of teaching (presenting mathematical ideas, modifying tasks, evaluating student claims, etc.) requires knowledge beyond that taught to students.

Horizon Knowledge (HK) Awareness of how mathematical topics are related, vision useful in seeing connections to later mathematical ideas.

Knowledge of Content and Students Ability to anticipate what students might think, ability to predict what is (KCS) interesting and motivating to students, ability to hear and interpret students' thinking, ability to anticipate what students will do with a task, knowledge of students' common conceptions and misconceptions.

Knowledge of Content and Teaching Sequencing content for instruction, choosing examples and when to use them, (KCT)

Knowledge of Content and Curriculum (KCC) evaluate instructional advantages and disadvantages of representations, understanding what different methods and procedures afford instructionally. Full range of programs designed for teaching particular subjects and topics, variety of instructional materials available, characteristics serving as both indications and contradictions for use of particular curriculum or materials.

Table 8. Themes used to analyze Qualitative data

\begin{tabular}{|c|c|}
\hline Themes & Data source Questions to guide my analysis \\
\hline $\begin{array}{l}\text { Teacher educator's } \\
\text { background }\end{array}$ & $\begin{array}{c}\text { Interview Tell me a little about your back ground? Like educational background, professional } \\
\text { experience, service years in CTEs, special training taken on subject areas }\end{array}$ \\
\hline SMK and its components & Interview How do you understand the term subject matter knowledge (SMK)? \\
\hline PCK and its components & Interview How do you understand the term pedagogical content knowledge (PCK)? \\
\hline $\begin{array}{l}\text { MKT and its relation with } \\
\text { SMK and PCK }\end{array}$ & $\begin{array}{l}\text { Interview How do define the term Mathematical Knowledge for Teaching (MKT)? How do } \\
\text { you think about its relation with SMK and PCK? }\end{array}$ \\
\hline $\begin{array}{l}\text { General comments about } \\
\text { the programs }\end{array}$ & $\begin{array}{l}\text { Interview What comments and suggestions do you have about the ongoing teacher education } \\
\text { program in Ethiopia? }\end{array}$ \\
\hline
\end{tabular}

knowledge without that being problematic (McCallum, Arekere, Green, Katz, \& Rivers, 2006; Prabhu, Patil, \& Kangokar, 2013).

This part of the study was focused on the analysis of each teacher educator's awareness and knowledge about MKT. The results were used to know the level of teacher educator's awareness of MKT.

After all audio recordings were completed, transcription (verbatim/exactly word-for-word) was made and then qualitative analysis against the major components of the MKT model was conducted. So, the indicators are served as thematic and analyzed against them.

In addition, for the sake of analysis purpose and confidentiality, each teacher educators were given pseudo names. Accordingly, the nine teacher educators would have names: TE-1, TE-2, TE-3, TE-4, ...TE-9 and their interviews were analyzed across a list of indicators of mathematics knowledge for teaching (MKT) which were extracted from Ball and her colleague's framework of MKT. They were asked questions that have a direct relation with the concept of components of MKT and MKT itself. Their responses were transcribed verbatim and analyzed qualitatively to create a vivid description of each interview. The response's patterns and the results allowed to depict how is individual teacher educators' MKT knowledge or awareness.

The first question of the interview focused on their background which includes about qualification and special Training has taken especially on subject area methodology whereas the $2^{\text {nd }}, 3^{\text {rd }}$ and $4^{\text {th }}$ questions were designed just for purpose of brainstorming about the SMK, PCK, and MKT. The final question was required to describe their general feeling about mathematics education and teacher education programs.

In general, the main essence of conducting interview was to look closely the current awareness of mathematics teacher educators of MKT and its components. The following part described the transcribed responses of the interviewees across each question from the three colleges of teacher education.

\section{Mathematics Teacher Educator's Background}

The first part of the interview was about selfintroduction and they were asked to explain themselves in terms of their professional background, service year in college of teacher education, and special training on teaching of various contents of mathematics.

All of the nine teacher educators have $2^{\text {nd }}$ degree in mathematics with various specialization like optimization, mathematics education, and differential. 
They have served in the college of teacher education from 1 to 20 years, and they have been teaching various courses like Geometry, Statistics, and Teaching Mathematics (TeMa). Two of them begin the teaching profession from teaching at primary school level and one has university experience and the rest have only college of teacher education experience.

Regarding the special training on teaching various mathematical contents, most of them didn't take special training on teaching methodologies of mathematics or content-based training specific to mathematics. However, three teacher educators (took some pedagogical courses when they were university student like curriculum and lesson plan preparations), all of them have taken training at least one time on generic pedagogies after they became teachers in the college of teacher education like continuous assessment, active learning methods, action research and the like.

\section{Awareness of Mathematics Teacher Educators}

The researcher described SMK and PCK in ways that different authors like Ball, Shulman, Mishra, Kohler, and others were defined and used different models with various components. Then the researcher asked teacher educators how they perceive or define SMK and PCK. Finally, time was given to them to describe MKT in relation to SMK and PCK or in anyways they perceived. All the questions were followed by probes.

Ball and her colleagues (2008) defined SMK in terms of three components: CCK, SCK, and HK. For them, CCK is Mathematical knowledge and skills not unique to teaching whereas SCK is Mathematical knowledge and skills unique to teaching like mathematical tasks of teaching (presenting mathematical ideas, modifying tasks, evaluating student claims, etc.) requires knowledge beyond what is taught to students. HK is an awareness of how mathematical topics are related; vision useful in seeing connections to later mathematical ideas.

However, all of the nine-teacher educators perceived SMK as the mathematical content knowledge they specialized or the mathematical contents they teach. They were unable to explain or define it in terms of CCK, SCK, and HK. But their responses were in line with the definition of SMK given by Prestage and Perks (1999); that is subject matter knowledge (SMK) refers to the body of knowledge and information about its structure, the body of concepts, facts, skills and definitions as well as methods of justification and proof, and Gudmundsdottir (1987) defined it as the teacher's understandings of the subject she/he teaches.

The responses of teacher educators indicated that they defined SMK in the same way, which is SMK is the knowledge of the content they teach. On the contrary, TE-1 and TE-9 reserved to say something about or defining SMK. None of them have tried to describe its components. For example, one teacher educator said:

TE-3: SMK is the hard (solid) part of mathematics. It is the basic/necessary mathematical content to teach the students. But I don't know whether it has subcomponents or not. I can say nothing about it.

Following their responses to SMK, the researchers have continued the interview and asked them and described it as PCK was described above. According to Ball and her colleagues (2008), PCK has three subcomponents: KCS, KCT, and KCC. KCS is considered as the ability to anticipate what students might think, ability to predict what is interesting and motivating to students, ability to hear and interpret students' thinking, ability to anticipate what students will do with a task, knowledge of students' common conceptions and misconceptions. Whereas KCT is sequencing content for instruction, choosing examples and when to use them, evaluate instructional advantages and disadvantages of representations, understanding what different methods and procedures afford instructional. Full range of programs designed for teaching particular subjects and topics, a variety of instructional materials available, characteristics serving as both indications and contradictions for use of particular curriculum or materials are included under KCC. However, Shulman (1987) defined Pedagogical content knowledge (PCK) as the blending of content band pedagogy into an understanding of how particular topics, problems, or issues are organized, represented, and adapted to the diverse interests and abilities of learners and presented for instruction. Similarly, Shulman and Sykes (1986) define PCK as the ability to: understand the central topics, skills, and attitudes in a field, know what aspects of these topics will be interesting and/or difficult to understand for students, develop and/or select examples that best represent central ideas in a field and question students effectively about these topics.

The interview transcriptions indicated that except three of them, the rest teacher educators have little awareness about PCK in ways that PCK is a term which is commonly used in the pedagogy of mathematics and perceived as it is dealing in one or another way with how to deliver/teach the course using various teaching methods which is to some extent aligned with the definition of PCK offered by Ding, He \& Leung, (2014). That is, PCK is regarded as a tool for teachers to deliver the content knowledge in their minds to pupils in a comprehensive manner. However, none of them defined in terms of its components as many authors defined like Ball et al. (2008), Lim-Teo et al. (2007), and Shulman (1987). For example, one teacher educator responded:

TE-6: I understand that PCK is a term related to the pedagogy of teaching and learning and I defined it as the way/techniques/method to transfer the knowledge 
Table 9. Summary of the responses of teacher educators on interview about SMK, PCK and MKT

\begin{tabular}{|c|c|c|c|c|c|}
\hline Educators & Special Training on Teaching Mathematics & Training on generic pedagogy & $S M K$ & PCK & MKT \\
\hline TE-1 & No & Yes & No & No & No \\
\hline TE-2 & No & No & Yes & No & No \\
\hline TE-3 & No & No & No & Yes & No \\
\hline TE-4 & No & Yes & Yes & Yes & No \\
\hline TE-5 & No & Yes & Yes & No & No \\
\hline TE-6 & No & Yes & Yes & Yes & Yes \\
\hline TE-7 & No & Yes & Yes & Yes & No \\
\hline TE-8 & No & Yes & Yes & Yes & Yes \\
\hline TE-9 & No & Yes & Yes & Yes & No \\
\hline
\end{tabular}

to our students. But I don't have any awareness about its components.

Regarding MKT, teacher educator's responses indicated that they have no awareness or knowledge about the concept of MKT and even they were unable to associate with SMK and PCK. For example, the response of one of the teacher educators was as follows

TE-1: To be honest, I have no awareness of these pedagogical terminologies. I can't define them. Even I don't know about their components and mathematical knowledge for teaching (MKT) in general.

However, MKT is a term introduced by Ball and her colleagues in 2008 by expanding the work of Shulman work of PCK and they defined MKT as the mathematical knowledge, skills and, behavior (habit of mind) needed to carry out the work of teaching mathematics (Ball, Thames, \& Phelps, 2008). It consists of two components: subject matter knowledge (SMK) and pedagogical content knowledge (PCK). No one was tried to explain MKT as Ball and her colleagues defined. They don't know the definition of MKT but two of them gave sound definition and were tried to define it in some ways similar to Ball's definition. Their responses were as follows:

TE-6: I think it deals with the integration of content knowledge and pedagogical knowledge.

TE-8: I think this is the knowledge needed to teach mathematics as I understand from the term itself. So, it contains content knowledge and pedagogical knowledge and another necessary knowledge. I think this is the relation between MKT, PCK, and SMK. But I am not sure whether this definition is correct or not.

In conclusion, the analysis of the interview of teacher educators against the indicators of mathematical knowledge for teaching (MKT), almost all of them have poor and/or no awareness about SMK and PCK and their sub-components. The result also indicated that all of them likely to have no enough knowledge about MKT and its components.

In Table 9, "Yes" means teacher educators mentioned some or little phrases that have some affiliation with the terminologies like SMK, PCK, and MKT but not in similar ways as shown in the indicator table. On the other hand, "No" is assigned to those who were unable to define the terminologies and have no ideas about the terminologies.

As a summary, it is possible to see that all of them hadn't got the opportunity to participate in the subject (mathematics) specific training. All of them except two teacher educators did not have awareness about MKT. Overall, the interview result showed that teacher educators have no satisfactory awareness about the term SMK, PCK, and MKT, and not got adequate training opportunities for teaching mathematics pedagogies.

Furthermore, teacher educators finally were asked to express their feelings, general comments or to say something on the ongoing teacher education program in Ethiopia regarding the knowledge the pre-service teachers and teacher educators should have and the entire mathematics teaching-learning process in CTEs. From the general comments forwarded by teacher educators, they feel that the generalist program is not the right program to train pre-service teachers for primary school. Of course, there are teacher educators who felt that specialist modality too. Whereas specialists and linear have relatively better curricula design to training teachers even though some questions remained. One of the reasons for this was in generalist modality, students were required to take several wide courses from four different departments which made them unable to master a single subject (mathematics). The following response of teacher educator taken as an example:

TE-1: In generalist modality, pre-service mathematics teachers taught various subjects from different departments (Mathematics, biology, chemistry, and physics) within three years. It is full of junk in various courses. This made them unable to concentrate on mathematics which results in not having the required knowledge of mathematic content for teaching mathematics..... I can say that specialist and linear modalities are better than generalist one but the specialist program was phaseout (interrupted) in our college. Anyways, Pre-service mathematics teachers in linear have a relatively better knowledge of mathematics even though some issues related to filling 
the basic knowledge gaps of pre-service mathematics teachers remain questions....

The other was regarding the pedagogical knowledge of teacher educators there are teacher educators who felt that they have not enough knowledge of pedagogies, though, they believed that they are good in subject matter knowledge like pedagogy. For example, teacher educators said:

TE-8: .... when I came to us, teacher educator, I do not doubt mathematical content knowledge of the subject, but my question is, do teacher educators have the necessary pedagogical to teach the courses in appropriate ways so that their students capture the desired knowledge at the end.

TE-7: .... in general, if we talk, the teacher education program has a lot of problems. We, teacher educators, have gaps in knowledge of pedagogies ....

These indicated that teacher educators believed that deficiency of pedagogical knowledge or fragmented knowledge of pedagogies created a knowledge gap on student's knowledge which in turn made the college of teacher education unable to produce competent primary school mathematics teachers who are able to have deep knowledge of mathematics.

\section{DISCUSSION}

Various authors are repeatedly indicated that MKT are critical for effective teaching (Morris, Hiebert, \& Spitzer, 2009). In addition, various findings showed that the appropriate places for developing and improving such knowledge were colleges of teacher education or universities since pre-service mathematics teachers have an access to learn subject method, content courses as well as method only courses in these sites (Jakobsen, Kazima, \& Kasoka, 2018). Pre-service mathematics teachers were appreciated the importance of MKT education in pre-service mathematics teacher education program and practice of MKT. Pre-service mathematics teachers' MKT has also a strong association with their performance in the teaching practices (Charalambous, 2008) which was significantly related to student achievement gains in both primary and secondary school (Ball, Hill, \& Bass, 2005)

However, number of studies showed pre-service mathematics teachers have been got difficulties in MKT task items which required CCK, SCK, KCS, KCT, and the proportions of those who showed appropriate knowledge on the items was less than 50\% (Han, 2016; Ndlovu, Amin, \& Samuel, 2017). Even, pre-service teachers at the primary and secondary performed below average score for both mathematics content knowledge and mathematics pedagogical content knowledge and performed worse at MKT items in general (Calli, 2015; Leong, Meng, Rahim, \& Syrene, 2015) and had difficulties within both knowledge domains, common content knowledge and specialized content knowledge (Johannsdottir, 2013). The information gained from these research support the findings of this study, that is difficulties in MKT task of pre-service mathematics teachers in the final year of the program. Other findings of this study were that female pre-service mathematics teachers were not significantly scored better than the male counterpart which was coincided with an overview on sex differences relative to aspects of MKT achievement (Corkin, Ekmekci, \& Papakonstantinou, 2015).

Moreover, teacher educators are one of the determinants parts for the quality teaching-learning process. Because they play an important role in helping pre-service teachers to acquire the knowledge needed for teaching, that is, developing deep and conceptual knowledge of the mathematics that they will teach (Ball \& Bass, 2000; Greenberg \& Walsh, 2008). In short, as many believed quality teacher preparation depends on quality educational inputs like quality teacher educators. Mason and Davis (2013) argued that a teacher who is aware, not only of the subject matter but of the pedagogical aspects of the subject matter is in a position to direct student attention to what matters, to what choices are available and to what criteria might be applied, when working with students on exercises and worked examples.

In addition, Mason and Davis (2013) delineated three different questions that framed much of the research into teachers' disciplinary knowledge of mathematics since the 1970s. They stated as

"What mathematics do teachers need to know to teach mathematics? (Teachers need to know more advanced mathematics than the mathematics they are teaching.), What specialized mathematics do teachers need to know in order to teach mathematics? (Teachers require multi-faceted specialized mathematics that involves, among other components, pedagogical content knowledge and specialized content knowledge.) and What mathematical knowledge is entailed by the work of teaching mathematics? (Teachers' mathematical knowledge is enacted in their daily work and must be unpacked)."

Simply put, it is reasonable to assume that quality teacher preparation depends on quality teacher educators. In this regard, numerous international scholars have written extensively about the need to examine teacher educator knowledge and tried to break the silence surrounding teacher educator quality (Berry, 2007). The majority of them found out that teacher educators need to go beyond pedagogy and develop a pedagogy of teacher education on definite priorities and corresponding strategies (Goodwin \& Kosnik, 2013). A significant number of studies found out that there were teacher educators who lacked or were unable to demonstrate the knowledge components that would have helped them to meet their goals, despite having a 
wealth of experience teaching and designing mathematics content courses for pre-service primary teachers (Olanoff, 2011), which is consistent with the findings of this study, that is, there are teacher educators who were unable define and clearly describe MKT and its components. They were unable to define means indirectly inform that teacher educators did not know the concept of MKT which is one of the recently proposed pedagogy on mathematics education. They could not go beyond the content knowledge they specialized in.

\section{CONCLUSION AND RECOMMENDATION}

Relevance is one indicator of education quality. Assessing the relevance of the education program directly measures how much the ongoing program is quality or not. Some of the indicators of quality education among others are teacher's content knowledge and student's knowledge.

As has been found in the study, pre-service mathematics teacher's knowledge in MKT scale test in all of the three modalities were very poor and their respective teacher educators have no satisfactory awareness about MKT which might create a knowledge gap on student's knowledge which in turn made the college of teacher education unable to produce quality and competent primary school mathematics teachers. Thus, in this study, the relevance of mathematics teacher education program in the college of teacher education is not satisfactory in terms of pre-service mathematics teacher's knowledge and teacher educator' awareness of MKT.

Therefore, the concerned stakeholders like teacher education college, regional education bureau and NGO who are working in teacher education should organize regular trainings in order to help teacher educators to develop/build knowledge of MKT and help them to conduct educational research to evaluate and analyze the curricula materials of mathematics education in terms of MKT. In addition, sessions (possibly regularly) should be arranged or include contents of MKT in already the ongoing programs like ESDPs to equip teacher educators with the knowledge, and habit of mind to succeed in supporting pre-service teachers to master aspects of mathematics. This in tun help them to recognize and articulate how their instruction goes and what teachers think about MKT in instruction.

Author contributions: All authors have sufficiently contributed to the study, and agreed with the results and conclusions.

Funding: No funding source is reported for this study.

Declaration of interest: No conflict of interest is declared by authors.

\section{REFERENCES}

Adelodun, O. A. (2014). Relevance of the mathematics education programmes of the Nigerian colleges of education to the teaching of junior secondary mathematics. Journal of Education and Practice, 5(7), 24-28.

Ball, D. L. (1990). The mathematical understandings that prospective teachers bring to teacher education. The Elementary School Journal, 90(4), 449-466. https:/ / doi.org/10.1086/461626

Ball, D. L., \& Bass, H. (2000). Interweaving content and pedagogy in teaching and learning to teach: Knowing and using mathematics. Multiple Perspectives on the Teaching and Learning of Mathematics, 4, 83-104.

Ball, D. L., Hill, H. C., \& Bass, H. (2005). Knowing mathematics for teaching: Who knows mathematics well enough to teach third grade, and how can we decide? American Educator, 29(1), 14-17, 20-22, 43-46.

Ball, D., Thames, M. H., \& Phelps, G. (2008). Content knowledge for teaching: What makes it special? Journal of Teacher Education, 59(5), 389-407. https:/ / doi.org/10.1177/0022487108324554

Berry, A. (2007). Tensions in teaching about teaching: Understanding practice as a teacher educator (Vol. 5). Springer Science \& Business Media. https:/ / doi.org/10.1007/1-4020-5993-0

Birhanu, M, A. (2010). Active learning approaches in mathematics education at universities in Oromia, Ethiopia. LAP LAMBERT Academic Publishing.

Bjarnadóttir, K. (2007). Fundamental reasons for mathematics education in Iceland. Monograph 1, 137-150. https:/ / doi.org/10.1201/b10579-11

Calli, E. (2015). A quantitative investigation of mathematical knowledge for teaching and self-efficacy: middle school mathematics teachers in Turkey (Master's thesis). Bilkent University.

Charalambous, C. Y. (2008). Preservice Teachers' Mathematical Knowledge for Teaching and Their Performance in Selected Teaching Practices: Exploring a Complex Relationship (Doctoral dissertation). The University of Michigan. http://hdl.handle.net/ 2027.42/61673

Corkin, D. M., Ekmekci, A., \& Papakonstantinou, A. (2015). Antecedents of teachers' educational beliefs about mathematics and mathematical knowledge for teaching among in-service teachers in high poverty urban schools. Australian Journal of Teacher Education, 40(9), 3. https://doi.org/10.14221/ ajte.2015v40n9.3

Cristobal, E., Flavian, C., \& Guinaliu, M. (2007). Perceived e-service quality (PeSQ): Measurement validation and effects on consumer satisfaction and 
web site loyalty. Managing Service Quality, 17(3), 317-340.

https:/ / doi.org/10.1108/09604520710744326

Dawit, M., \& Alemayehu, B. (2001). Pre-service Teachers' perception towards professional courses and The Efficacy of subject Methodology courses in Developing Pedagogical Content Knowledge. The Ethiopian Journal of Education, 21(2), 21-60.

Ding, L., He, J., \& Leung, F. K. S. (2014). Relations between subject matter knowledge and pedagogical content knowledge: A study of Chinese pre-service teachers on the topic of threeterm ratio. The Mathematics Educator, 15(2), 50-76.

Fennema, E., \& Franke, M. L. (1992). Teachers' knowledge and its impact. In D. A. Grouws (Ed.), Handbook of research on mathematics teaching and learning: A project of the National Council of Teachers of Mathematics (pp. 147-164). Macmillan Publishing Co, Inc.

Gallagher, J. J., Floden, R. E., \& Gwekwerere, Y. (2012). Context for Developing Leadership in Science and Mathematics Education in the USA. In Second International Handbook of Science Education (pp. 463476). Springer. https://doi.org/10.1007/978-14020-9041-7_32

Ganley, C. M., \& Lubienski, S. T. (2016). Mathematics confidence, interest, and performance: Examining gender patterns and reciprocal relations. Learning and Individual Differences, 47, 182-193. https:// doi.org/10.1016/j.lindif.2016.01.002

Garson, G. D. (2012). Testing statistical assumptions. Statistical Associates Publishing.

Goodwin, A. L., \& Kosnik, C. (2013). Quality teacher educators=quality teachers? Conceptualizing essential domains of knowledge for those who teach teachers. Teacher Development, 17(3), 334-346. https:/ / doi.org/10.1080/13664530.2013.813766

Gravetter, F., \& Wallnau, L. (2014). Introduction to the statistic. Essentials of Statistics for the Behavioral Sciences, 8, 252.

Greenberg, J., \& Walsh, K. (2008). No Common Denominator: The Preparation of Elementary Teachers in Mathematics by America's Education Schools. National Council on Teacher Quality.

Gudmundsdottir, S. (1987). Pedagogical content knowledge: teachers' ways of knowing [Paper presentation]. Annual Meeting of the American Educational Research Association, Washington, DC.

Han, H. (2016). A study on pre-service mathematics teachers' MKT. Communications of Mathematical Education, 30(1), 101-120. https:/ / doi.org/10.7468/ jksmee.2016.30.1.101

Hauk, S., Jackson, B., \& Tsay, J-J. (2017). Those who teach the teachers: Knowledge growth in teaching for mathematics teacher educators. In A. Weinberg, C.
Rasmussen, J. Rabin, M. Wawro, and S. Brown (Eds.), Proceedings of the 20th Annual Conference on Research in Undergraduate Mathematics Education (pp. 428-439), San Diego, California.

Hiebert, J., Morris, A. K., Berk, D., \& Jansen, A. (2007). Preparing teachers to learn from teaching. Journal of Teacher Education, 58(1), 47-61. https:/ / doi.org/10.1177/0022487106295726

Hill, H. C., \& Ball, D. L. (2009). The curious- and crucialcase of mathematical knowledge for teaching. Phi Delta Kappan, 91(2), 68-71. https://doi.org/ 10.1177/003172170909100215

Hill, H. C., Schilling, S. G., \& Ball, D. L. (2004). Developing measures of teachers' mathematics knowledge for teaching. The Elementary School Journal, 105(1), 11-30. https://doi.org/10.1086/ 428763

Jakobsen, A., Kazima, M., \& Kasoka, D. N. (2018). Assessing prospective teachers' development of MKT through their teacher education: A Malawian case. In E. Norén, H. Palmér, \& A. Cooke (Eds.) Papers of NORMA 17, The eighth Nordic conference on mathematics education, Stockholm, May 30-June 2, 2017 (pp. 219-227). Swedish Society for Research in Mathematics Education.

Johannsdottir, B. (2013). The mathematical content knowledge of prospective teachers in Iceland. Teachers College.

Jonasson, J. T. (2010). PLA Iceland: Issues related to teacher educators. http://www3.hi.is/ jtj/PLA\%20June/ PLAJune2010do.htm

Kassa, M. (2014). Mathematics teacher education and teachers' professional competence in Ethiopia ( $\mathrm{PhD}$ dissertation).

Kelly, A. V. (1999). The curriculum: Theory and practice $\left(4^{\text {th }}\right.$ Ed.). Sage.

Koster, B., Dengerink, J., Korthagen, F., \& Lunenberg, M. (2008). Teacher educators working on their own professional development: Goals, activities and outcomes of a project for the professional development of teacher educators. Teachers and Teaching, 14(5-6), 567-587. https:// doi.org/10.1080 /13540600802571411

Kvale, S. (1996). InterViews: An introduction to qualitative research interviewing. Sage.

Lee, J., Meadows, M., \& Lee, J. O. (2003). What Causes Teachers to Implement High-Quality Mathematics Education More Frequently: Focusing on Teachers' Pedagogical Content Knowledge [Paper presentation]. 2003 Association for Childhood Education International (ACEI) International Annual Conference, Phoenix, AZ.

Leech, N., Barrett, K., \& Morgan, G. (2008). SPSS for intermediate statistics: Use and interpretation. Erlbaum Associates. 
Leong, K. E., Chew, C. M., \& Abdul Rahim, S. S. (2015). Understanding Malaysian Pre-Service Teachers Mathematical Content Knowledge and Pedagogical Content Knowledge. Eurasia Journal of Mathematics, Science and Technology Education, 11(2), 363-370.

https://doi.org/10.12973/eurasia.2015.1346a

Levene, H. (1960). Robust tests for equality of variances. In I. Olkin, S. G. Ghurye, W. Hoeffding, W. G. Madow, \& H. B. Mann (Eds.), Contributions to Probability and Statistics (pp. 278-292). Stanford University Press.

Lewin, K. M., \& Stuart, J. S. (2003). Researching teacher education: new perspectives on practice, performance and policy. DFID.

Lim-Teo, S. K., Chua, K. G., Cheang, W. K., \& Yeo, J. K. (2007). The development of diploma in education student teachers' mathematics pedagogical content knowledge. International Journal of Science and Mathematics Education, 5(2), 237-261. https:/ / doi.org/10.1007/s10763-006-9056-5

Mapolelo, D. C., \& Akinsola, M. K. (2015). Preparation of mathematics teachers: Lessons from review of literature on teachers' knowledge, beliefs, and teacher education. International Journal of Educational Studies, 2(1), 01-12.

Mason, J., \& Davis, B. (2013). The importance of teachers' mathematical awareness for in-the-moment pedagogy. Canadian Journal of Science, Mathematics and Technology Education, 13(2), 182-197. https: / / doi.org/10.1080/14926156.2013.784830

McCallum, J. M., Arekere, D. M., Green, B. L., Katz, R. V., \& Rivers, B. M. (2006). Awareness and knowledge of the US Public Health Service syphilis study at Tuskegee: implications for biomedical research. Journal of Health Care for the Poor and Underserved, 17(4), 716. https://doi.org/10.1353/ hpu.2006.0130

Meena, W. (2009). Curriculum innovation in teacher education: exploring conceptions among Tanzanian teacher educators. Abo Academi University Press.

Ministry of Education (2013). Curriculum Framework for Primary Pre-service Education. Author

Ministry of Education (2016). Evaluating teacher training practices in Ethiopia across modalities: Focus on primary and pre-primary Future Program. Author.

Ministry of Education (MoE). (2006). Action Research in Primary Schools in Ethiopia, Ministry of Education and Academic for Educational Development, and United States Agency for International Development, AA. Ethiopia.

Mishra, P., Pandey, C. M., Singh, U., Keshri, A., \& Sabaretnam, M. (2019). Selection of appropriate statistical methods for data analysis. Annals of
Cardiac Anaesthesia, 22(3), 297. https://doi.org/ 10.4103/aca.ACA_248_18

Morris, A. K., Hiebert, J., \& Spitzer, S. M. (2009). Mathematical knowledge for teaching in planning and evaluating instruction: What can preservice teachers learn? Journal for research in mathematics education, 40(5), 491-529. https:/ / doi.org/10.5951/ jresematheduc.40.5.0491

National Council for teachers of mathematics (2000). Principles and standards for school mathematics. Author.

Ndlovu, Z., Amin, N., \& Samuel, M. A. (2017). Examining pre-service teachers' subject matter knowledge of school mathematics concepts. Journal of Education (University of KwaZulu-Natal) (70), 4672.

Olanoff, D. E. (2011). Mathematical knowledge for teaching teachers: The case of multiplication and division of fractions. Syracuse University.

Osaki, K. M. (2000). Reflection on the change processes implied in the teacher education master plan in Tanzania. In G. Höjlund, N. Mtana, \& E. Mhando (Eds). Practices and possibilities in teacher education in Africa: Perspectives from Tanzania. Ecoprint.

Prabhu, M., Patil, S. H., \& Kangokar, P. C. R. (2013). Glaucoma awareness and knowledge in a tertiary care hospital in a tier-2 city in South India. Journal of the Scientific Society, 40(1), 3. https: / / doi.org/10.4103/0974-5009.109674

Prestage, S., \& Perks, P. (1999). Subject matter knowledge in experienced and novice teachers of mathematics [Paper presentation]. British Educational Research Association Conference, University of Sussex, at Brighton. http://www.leeds.ac.uk/educol/ documents/000001168.htm

Shulman, L. (1987). Knowledge and teaching: Foundations of the new reform. Harvard Educational Review, 57(1), 1-23. https://doi.org/10.17763/ haer.57.1.j463w79r56455411

Shulman, L. S., Sykes, G., Education, T. F. o. T. a. a. P. C. F. o., \& Economy, t. (1986). A national board for teaching? In search of a bold standard. Carnegie Corporation.

Sutton, J., \& Krueger, A. (2002). EDThoughts: What We Know about Mathematics Teaching and Learning. National Network of Eisenhower Regional Consortia and National Clearinghouse; Association of State Supervisors of Mathematics.; Mid-Continent Research for Education and Learning, Aurora, CO.

Tatto, M. T., Peck, R., Schwille, J., Bankov, K., Senk, S. L., Rodriguez, M., Ingvarson, L., Reckase, M., \& Rowley, G. (2012). Policy, Practice, and Readiness to Teach Primary and Secondary Mathematics in 17 Countries: Findings from the IEA Teacher Education 
and Development Study in Mathematics (TEDS-MM). International Association for the Evaluation of Educational Achievement.

Thames, M. H., \& Ball, D. L. (2010). What Math Knowledge Does Teaching Require? Teaching Children Mathematics, 17(4), 220-229. https://doi.org/10.5951/TCM.17.4.0220

Trochim, W., \& Donnelly, J. (2006). The research methods knowledge base. Atomic Dog Publishing Inc

UNICEF. (2010). Defining quality in education [Paper presentaion]. UNICEF at the meeting of the international working group on education. Florence, Italy, June.
Weiss, R. S. (1994). Learning from strangers: The art and method of qualitative interview studies. Free Press.

Workneh, A., \& Tessema, W. (2013). Teacher training and development in Ethiopia: Improving education quality by developing teacher skills, attitudes and work conditions. Young Lives.

Yohannes, G. (2007). Barriers to teaching and learning mathematics in grade four: a study in one primary school in Addis Ababa, Ethiopia (Master's thesis), Department of Special Needs Education, Faculty of Education, University of Oslo, Norway.

\section{http://www.ejmste.com}

